Transitions

X Paul-Pierre

Pastoret will succeed

Chris Bostock as

director of Britain's

Institute for Animal

Health later this year.

Pastoret is currently

head of the immunology

and vaccinology unit in

the faculty of veterinary

medicine at the

University of Liège,

Belgium.

$\mathrm{X}$ Stef Heylen will join

Dutch antibody and

vaccine company

Crucell as vice-

president of

development and

regulatory affairs on 1

March. Before joining

Crucell, Heylen was

vice-president of

medical affairs for

Europe, Middle East and

Africa at Janssen-Cilag.

He has worked for the

Janssen Research

Foundation since 1987

in various senior

management positions.

X Last November

Genome Prairie, an

initiative on wheat and

canola genomics

backed by the Canadian

government, appointed

Randal Johnston as its

first president and chief

executive. Johnston

gave up the directorship

of the Southern Alberta

Cancer Research Centre

and a post as associate

vice-president of

research at the

University of Calgary to

take up the new job.

$\mathrm{X}$ Linguist Jean-Marie

Hombert this month

succeeded Marie-

Claude Maurel as

director of the

department of

humanities and social

sciences at the CNRS,

the French scientific

research agency.

Hombert has been a

professor of linguistics

at Lumière-Lyon 2

University since 1980

X Christoph Leemann succeeds Hermann Grunder as director of the Thomas Jefferson National Accelerator Facility in Newport

News, Virginia.

Leemann has been

interim director since

Grunder left to head the

Argonne National

Laboratory in 2000.

\section{SPACE MEDICINE}

Jeffrey Sutton didn't have a clear destination in mind as he navigated a career path that switched from medical training to graduate work in neuroscience to a $\mathrm{PhD}$ in theoretical physics. "I never really knew where it would lead - except I was having a lot of fun along the way," he says.

But his varied career helped to prepare him for his new position as director of the National Space Biomedical Research Institute in Houston, Texas, a consortium aimed at developing solutions to medical problems encountered during space flights. His background will help him to examine areas such as the effects of deep-space radiation on a spacecraft's occupants and the impact of zero gravity on bone and muscle.

A key aim of the consortium is to design small, non-invasive ways to diagnose and treat medical problems. Sutton already has experience of medicaltechnology development with his previous joint appointments as head of the neural-systems group at the Massachusetts General Hospital and associate professor in the Harvard-MIT Division of Health Sciences and Technology. Including the effects of space adds another exciting variable. That challenge attracted him to the consortium in 1999 and is now drawing proposals from a number of high-profile scientists, including Nobel laureates.

"People want to be players," Sutton says. "Some of it is impact. Some of it is legacy. And some of it is pure fun." Although Sutton officially joined the consortium as director in November, he will move to Houston in June.

\section{CHEMISTRY}

After "a very long absence", British quantum chemist Peter Taylor is returning to England, thanks to a scheme designed to counteract the UK brain drain.

Taylor, currently deputy director of the San Diego Supercomputer Center at the University of California, San Diego, accepted a professorship in the University of Warwick's chemistry department. He will help to build up the university's recently established Centre for Scientific Computing - a smaller, more focused version of the San Diego centre.

Taylor left England at the age of 13, when his parents moved to Australia. He has spent the past 10 years at San Diego.

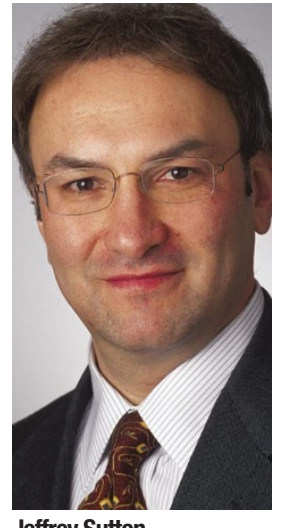

Jeffrey Sutton

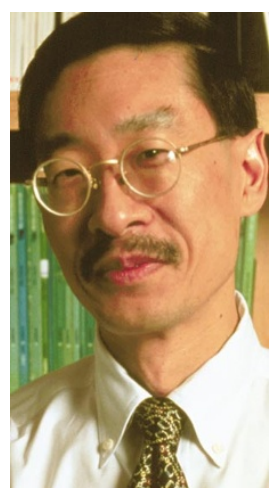

Dennis Choi

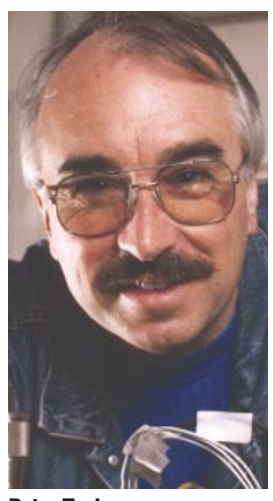

Peter Taylor
Although he'll miss the south California weather, he's keen to return to England, which he already visits regularly. A Royal Society-Wolfson Research Merit Award, which will supplement his pay, helped to attract him back.

Biologist Timothy Karr of the University of Chicago and Gabriel Aeppli of the NEC Research Institute in Princeton, New Jersey, also received the award. Karr is joining the University of Bath's department of biology and biochemistry. Details of Aeppeli's new post have not yet been released.

\section{PHARMACEUTICALS}

Dennis Choi this month joins another academic-turned-industrial-scientist, Peter Kim (see Movers, Naturejobs 12 July 2001), at Merck Research Laboratories in West Point, Pennsylvania.

Choi is leaving the Washington University School of Medicine in St Louis, Missouri, where he served for over 10 years as head of the neurology department and as Andrew B. and Gretchen P. Jones professor. He was also neurologist-in-chief at BarnesJewish Hospital in St Louis, Missouri, and founding director of the Center for the Study of Nervous System Injury at the Washington School of Medicine.

He is now executive vice-president, neurosciences, at Merck Research Laboratories and reports to Kim, who joined the company as executive vicepresident, research and development, last year.

Choi, whose research interest is in understanding the cellular mechanisms that underlie brain or spinal-cord injury in neurological disease states, made the move so that he could think more broadly about diseases of the nervous system. He has also always wanted to make an impact with therapies and he feels that he has a better opportunity in industry.

"I see this move as a logical extension of my career-long interest in translational research," says Choi. "I've always been focused on the bridge." He notes that the bridge between academia and the drugdevelopment industry is more tempting to cross now because drug development is becoming increasingly based on defined mechanisms rather than on large-scale screening of compounds against possible targets. As a result, academic and industrial career paths are becoming more "intertwined", says Choi. 